\title{
Olga Bashkir
}

doctor of pedagogy, associate professor, professor of the department of the educology and innovative pedagogy, H. Skovoroda Kharkiv National Pedagogical University;

Kharkiv, Ukraine

ORSID: 0000-0001-5237-9778

E-mail: boi83@ukr.net

\section{Svetlana Zolotukhina}

doctor of pedagogy, professor of the department of the educology and innovative pedagogy,

H. Skovoroda Kharkiv National Pedagogical University; Kharkiv, Ukraine

ORSID: 0000-0002-3535-5974

E-mail:kaf_pedagogik@ukr.net

\section{ICT MEANS IN THE FORMATION OF STUDENTS' COGNITIVE INTERESTS IN MASTERING A FOREIGN LANGUAGE LEXICAL COMPETENCE}

Abstract: the problem of preparation of students of general secondary education institutions for mastering a foreign language in the conditions of blended learning is considered. The efficiency of using information and communication technologies of blended learning in the formation of cognitive interest of students to master foreign language lexical competence is determined and proved.

Key words: foreign, English, learning, mixed, distance.

\section{Ольга Башкір}

доктор педагогічних наук, доцент, професор кафедри освітології та інноваційної педагогіки, Харківський національний педагогічний університет імені Г. Сковороди; Харків, Україна

E-mail: boi83@ukr.net

\section{Світлана Золотухіна}

доктор педагогічних наук, професор, професор кафедри освітології та інноваційної педагогіки, Харківський національний педагогічний університет імені Г. Сковороди; Харків, Україна

E-mail:kaf_pedagogik@ukr.net

\section{ЗАСОБИ ІКТ В ФОРМУВАННЯ ПІЗНАВАЛЬНИХ ІНТЕРЕСІВ УЧНІВ ДО ОВОЛОДІННЯ ЛЕКСИЧНОЇ КОМПЕТЕНЦІЇ ІНОЗЕМНОЇ МОВИ}

Анотаиія: розглянуто проблему підготовки учнів закладів загальної середньої освіти до оволодіння іноземною мовою в умовах змішаного навчання. Визначено та доведено ефективність використання інформаційно-комунікаційних технологій змішаного навчання у формуванні пізнавального інтересу школярів до оволодіння іншомовною лексичною компетентністю.

(c) Olga Bashkir, Svetlana Zolotukhina, 2021 
Ключові слова: іноземна, англійська, навчання, змішане, дистанційне.

\section{Ольга Башкир, Светлана Золотухина}

\section{СРЕДСТВА ИКТ В ФОРМИРОВАНИЯ ПОЗНАВАТЕЛЬНЫХИНТЕРЕСОВ, УЧАЩИХСЯ К ОВЛАДЕНИЮ ИНОСТРАННОЙ ЛЕКСИЧЕСКОЙ КОМПЕТЕНТНОСТЬЮ}

Аннотащия: рассмотрена проблема подготовки учащихся учреждений общего среднего образования к овладению иностранным языком в условиях смешанного обучения. Определена и доказана эффективность использования информационнокоммуникационных технологий смешанного обучения в формировании познавательного интереса школьников к овладению иностранной лексической компетентности.

Ключевые слова: иностранный, английский, обучение, смешанное, дистанционное.

\section{Ольга Башкір, Світлана Золотухіна}

\section{Розширена анотація для ознайомлення з цією темою: \\ “Засоби ІКТ у формуванні пізнавального інтересу учнів до оволодіння іншомовною лексичною компетентністю"}

Постановка проблеми в загальному вигляді та ї̈ зв'язок із важливими науковими чи практичними завданнями. Актуальним питанням педагогіки XXI сторіччя, $у$ зв'язку з реформуванням змісту освіти, форм і методів навчання в контексті впровадження Концепиії "Нова украӥнська школа", залишається проблема формування пізнавального інтересу здобувачів загальної середньої освіти, зокрема до оволодіння лексичною компетентністю англійської мови.

Аналіз останніх досліджень $i$ публікацій, у яких започатковано розв'язання иієї проблеми $і$ на які спирається автор. Проблема розвитку пізнавального інтересу до вивчення іноземної мови завжди була в иентрі уваги та порушувалась багатьма науковияли $i$ практиками, а сам феномен пізнавального інтересу вже протягом довгого часу залишається предметом трунтовних досліджень як вітчизняних, так $і$ зарубіжних пошукувачів.

Пошук ефективних та інноваиійних засобів інформаиійно-комунікаиійних технологій (IKT) для навчання лексики так, щоб ие було иікаво, залишається актуальним, адже в умовах карантинних обмежень, зумовлених поширенням Covid-19, важко зачікавлювати учнів закладів загальної середньої освіти (3ЗСО), ідучи традиційними иляхами.

Формулювання цілей статmі (постановка завдання). Одним із ключових завдань 3ЗСО є формування пізнавального інтересу, який є надважсливою умовою успішного протікання навчального прочесу, його продуктивності ци результативності за будь яких обставин, зокрема й під час змішаного навчання. Мета дослідження перевірити ефективність засобів IKT у формуванні пізнавального інтересу здобувачів загальної середньої освіти до оволодіння лексичною компетентністю на уроках англійської мови в умовах змішаного навчання.

Виклад основного матеріалу дослідження 3 повним обтрунтуванням отриманих наукових результатів. 3 метою перевірки рівня сформованості пізнавального інтересу здобувачів загальної середньої освіти до оволодіння 
лексичною компетентністю на уроках англійської мови нами було проведено експеримент, який складався $з$ трьох етапів: констатувального, формувального та контрольного. Експериментальнодослідницька робота проводилася під час педагогічної практики студентів факультету іноземної філологї Харківського національного педагогічного університет імені Г. Сковороди на базі Харківської спеціалізованої школи I-ІІІ ступенів №162 упродовж першого семестру 2020-2021 навчального року.

У відповідності з логікою дослідження нами були визначені етапи розвитку пізнавального інтересу школярів до вивчення англійської лексики: створення умов для виникнення пізнавального інтересу учнів до іншомовної лексики, ї практичного засвоєння; комплексне формування позитивного ставлення до англійської мови як навчального предмету; формування пізнавального інтересу до оволодіння лексичною компетентністю в умовах зміманого навчання. Дослідження було спрямоване на перевірку таких показників:

- ставлення до вивчення іноземної мови та оцінка ролі пізнавального інтересу у здобутті знань;

- прагнення поповнити $m a$ відтворити знання лексики, а також оволодіти способами ї застосування в нетипових ситуаціях;

- усвідомлення ролі інтелектуальної ініціативи в оволодінні лексичною компетентністю;

- прояв вольових зусиль в оволодінні лексичною компетентністю.

3 метою виявлення ступеня доцільності використаних засобів IКТ для формування пізнавального інтересу на констатувальному етапі було проведено оцінювання учнів їхніми викладачами, батьками, методистами та студентами-практикантами, а також самооиінювання $і$ взаємне оцінювання иколярів. $У$ результаті в учнів виявлено досить низький рівень пізнавального інтересу до іншомовної лексики за допомогою методів (високий - 12\%, середній - 51\%, низький - 37\%).

У ході формувального етапу дослідження встановлювалась доиільність та ефективність тих чи тих дій педагога на кожному з трьох етапів формування пізнавального інтересу до вивчення англомовної лексики:

- створення умов, які сприяють виникненню потреби у знаннях та $\ddot{x}$ засвоснні - враховували інтереси та потреби учнів, заохочували суперництвво, створювали ситуащї успіху, підвищували кваліфікацію вчителів у використанні сучасних засобів IКT дистанційного навчання;

- комплексне формування позитивного ставлення до навчального предмету й діяльності в контексті вивчення англійської мови - підібраний роздатковий матеріал для унаочнення нового навчального матеріалу, а також застосування нетрадиційних форм організації навчання, позакласної роботи, застосування прийом привабливої мети, мозкового штурму;

- формування пізнавального інтересу до оволодіння лексичною компетентністю в умовах зміманого навчання - безпосереднє виконання вправ на дистаниійних платформах, участь у проєктах, виконання досліджень, розробка структурно-логічних схем, таблиць, ментальних карт, інфографіки та скрайбінгу.

На кожному з етапів реалізації поставленої мети дослідження сприяли такі засоби IKT, як Microsoft Powerpoint, Zoom, Meet, Google Drive, Skype, Viber, Telegram, Kahoot, Classroom, Jamboard, Canva, Padlet, Flipgrig, iLearn, Trello, Mentimeter, Bubbl.us, Coggle, Popplet, MindMeister.

Ha заключному етапі експерименту було здійснено контроль ефективності проведеної роботи, завданням якого була перевірка рівня пізнавального інтересу до вивчення лек- 
сики на уроках англійської мови. Для очінки рівня пізнавального інтересу $у$ здобувачів загальної середньої освіти застосовувалися ті ж методи (опитування, анкетування, бесіда, спостереження, аналіз $i$ узагальнення результатів), які були використані на констатувальному етапі. Результати засвідчили оволодіння пізнавальним інтересом на високому рівні - 39\% учнів, на середньому - 57\%, на низькому - 4\%, щчо свідчить про ефективність використання зазначених

Problem setting. In connection with the reform of the content of education, forms and methods of teaching in the context of the implementation of the Concept "New Ukrainian School", the urgent issue of pedagogy of the XXI century remains the problem of the formation of the cognitive interest of applicants for general secondary education, in particular, to mastering the lexical competence of the English language.

General problem statement and its connection with important scientific or practical tasks. Topical issues of pedagogy of the XXI century, in connection with the reform of the content of education, forms and methods of teaching in the context of the implementation of the Strategy of the development of higher education in Ukraine for 2021-2031 [1], the Concept of the New Ukrainian School [2] remains a problem of forming the cognitive interest of students of general secondary education, in particular, mastering the lexical competence of the English language .

Cognitive interest is a powerful motivating force that directs a person to active learning activities, turning the latter into an exciting and emotional process. The ultimate goal of cognitive interest in mastering lexical competence is the emergence of students' inner need to learn new vocabulary, involves the involvement of the emotional sphere of the individual.

Recent research and publications analysis. The problem of developing cognitive interest in learning a foreign засобів IКТ зміманого навчання.

Висновки $з$ даного дослідження та перспективи подальших розвідок $у$ даному напрямку. Після проведення експерименту ми можемо констатувати якісні та кількісні зміни щуодо розвитку в учнів пізнавального інтересу до оволодіння лексичною компетентністю аналійської мови за умови використання засобів інформаційно-комунікаційних технологій змішаного навчання.

language has always been in the spotlight and has been raised by many scholars and practitioners, and the phenomenon of cognitive interest has long been the subject of serious research by both domestic and foreign applicants. Thus, A. Bashkir, A. Ilchenko [3], V. Lozova [7], N. Siranchuk [9] and others laid the theoretical foundation and formulated productive ideas for the development of cognitive interest of schoolers in the learning process. The phenomenon of cognitive interest is revealed in the works of such researchers as N. Bibik [4], V. Bondarevskiy [5], G. Shchukina [10] and others. V. Buchbinder [6], V. Tereshchuk [9] and others dealt with the formation of cognitive interest as an effective way of teaching foreign language vocabulary. The studies of V. Chan, M. Nagami [11], Meara, P. [12] and others were devoted to the peculiarities of the use of ICT in the study of vocabulary. However, the issue of forming the cognitive interest of students in general secondary education to master foreign language vocabulary in the context of blended learning remains out of the researchers' attention.

Highlighting of previously unresolved parts of the general problem to which this article is devoted. The process of the formation of cognitive interest in mastering the English-language lexical competence at the present stage remains poorly studied. The search for effective and innovative means of information and communication technologies (ICT) for 
teaching vocabulary in an interesting way remains relevant, because in the quarantine conditions caused by the spread of Covid19 , it is difficult to interest students of general secondary educational institutions, following traditional ways : sticking to the materials from familiar, authentic textbooks, encouraging students to memorize words in lists and translate dozens of sentences in a row. Preparing for lessons, a teacher really needs to focus not only on the requirements of state programs, trying to cover everything at once, regardless of the results and interest of students, but also to focus on the age, psychological characteristics and their own needs of students.

Paper objective. One of the key tasks of general secondary educational institutions is the formation of cognitive interest, which is an essential condition for the successful learning process, its productivity and effectiveness in all circumstances, including during blended learning. The purpose of the study is to test the effectiveness of ICT tools in the formation of cognitive interest of applicants for general secondary education to master lexical competence at English lessons in a blended learning environment.

In order to solve the set tasks, the following research methods were used: theoretical: analysis of psychological and pedagogical literature in order to determine the conceptual categorical apparatus; empirical: questioning, conversation, observation, survey, generalization, analysis of the products of educational and cognitive activity, pedagogical experiment; statistical: methods of mathematical statistics, allowed to quantitatively and qualitatively analyze the results of the study.

Paper main body. In order to check the level of formation of the cognitive interest of applicants for general secondary education in mastering lexical competence at English lessons, we conducted an experiment, which consisted of three stages: ascertaining, formative and control. The experimental research work was carried out during the teaching practice of students of the Faculty of Foreign Philology of H. Skovoroda Kharkiv National Pedagogical University on the basis of the Kharkiv specialized school IIII levels No. 162 during the first semester of the 2020-2021 academic year.

In accordance with the logic of the study, we identified the stages of development of students' cognitive interest in learning English vocabulary: creating conditions for the emergence of students' cognitive interest in foreign language vocabulary, its practical acquisition; complex formation of a positive attitude to English as a subject; formation of cognitive interest in mastering lexical competence in the conditions of blended learning. The study aimed to verify the following indicators:

- attitude to the study of a foreign language and assessment of the role of cognitive interest in gaining knowledge;

- the desire to supplement and reproduce the knowledge of vocabulary, as well as to master the methods of its application in atypical situations;

- awareness of the role of intellectual initiative in mastering lexical competence;

- manifestation of volitional efforts in mastering lexical competence.

In order to identify the appropriateness of the ICT tools used for the formation of cognitive interest at the ascertainment stage, students were evaluated by their teachers, parents, methodologists and interns, as well as self-assessment and mutual evaluation of students were conducted.

Basing on the conducted work, the levels of formation of students' cognitive interest in mastering lexical competence were distinguished: high, medium, low.

The high level is characterized by the manifestation of cognitive interest in the forming of an internal need for learning, predetermines the presence of significant volitional effort and painstaking work aimed at comprehending the procedure of lexical changes, to understand their theoretical and scientific foundations. Pupils try to delve 
systematically into more complex aspects of the English language, independently looking for additional information and carefully analyzing the information provided by the teacher. Schoolchildren have a positive perception of the learning environment, are motivated and capable of reflection. The acquisition of lexical competence is faster and more successful; the assimilation of knowledge is durable and conscious.

The medium level is characterized by the fact that students do not always aim at learning something new on their own. They more often strictly follow the teacher's instructions; less often, they take the process of their learning under their own control. Students are rarely engaged in selfeducation, the acquisition of knowledge for them is a formal process. Such students show less ability to reflect, are rarely the initiators of practical activities.

Those who do not have a positive attitude to learning have the low level. At lessons, such students are passive and uninitiated; they do not realize the importance of the material provided by the teacher. Consistency of lexical speaking skills is almost absent, which is the cause of a large number of lexical errors in speech. Students are not engaged in self-education, do not resort to reflection.

The effectiveness of ICT tools during the formation of cognitive interest was tested during the formative stage of the pedagogical experiment, which took place in the natural conditions of the pedagogical process. In the course of the research, the expediency and efficiency of certain actions of the teacher at each of the three stages of formation of cognitive interest in the study of English vocabulary were established. The experiment was conducted in such a way that, without violating the traditional curriculum, to increase the level of cognitive interest in students of general secondary education in English lessons in a blended learning environment.

In the study, we were guided by the fact that the process of increasing the level of cognitive interest in learning vocabulary should be gradual, taking into account that the teacher is not the initiator of increasing the interest, and students begin to aquire new knowledge, feeling some lack of them to communicate successfully or work with writing sources.

Speaking about creating conditions that contribute to the need for knowledge and their acquisition, we took into account the interests and needs of students, making their work interesting. In addition, we encouraged competition, which, however, did not go beyond healthy learning competition; also created situations of success for students who experience certain learning difficulties, focusing on achievements and encouraging them.

It is necessary to emphasize that the personal qualities of the teacher and the ability to make students interested in the subject, transmitting their own interest in it and professional awareness of the use of modern ICT are also one of the effective ways to increase students' cognitive interest in learning foreign language vocabulary. At this stage, teachers and students-interns had to master the methods of teaching in a blended learning environment, the use of media resources and information and communication technologies, which became a condition of distance learning.

In order to form a positive attitude to the subject and activities in the context of learning English, we have selected handouts to illustrate new learning materials, as well as the use of non-traditional forms of learning: a quiz lesson and an interactive lesson. In addition, students were involved in extracurricular activities: we had several conversations with them, where they identified difficulties that arise in the process of learning a foreign language, and together found ways to solve them, emphasizing the importance of cognitive interest.

In order to form a positive attitude to the study of English, the technique of attractive purpose was used in the research. The students had a simple, clear and attractive 
goal; achieving it, they involuntarily performed the educational action that the teacher planned. The technology of interactive learning "brainstorming", which successfully complements the reproductive forms of learning, contributed to the solution of creative, heuristic tasks while forming a positive attitude to the study of English vocabulary. This technology helped to train students' ability to express their thoughts concisely, clearly and variably, using the acquired lexical knowledge and skills, revealing general language awareness. This form of work interested students and often became the basis for organizing various activities in the classroom.

At the stage of formation of cognitive interest in mastering lexical competence in the context of blended learning, a number of ICT tools were used (Microsoft PowerPoint, Zoom, Meet, Google Drive, Skype, Viber, Telegram, Kahoot, Classroom, Jamboard, Canva , Padlet, Flipgrig, iLearn, Trello, Mentimeter, Bubbl.us, Coggle, Popplet, MindMeister), which provided the formation of students' cognitive activity before mastering English language competence. Thus, a learning set of words, phrases and stable expressions were created on the interactive services Quizlet and Kahoot! Students had the opportunity to practice lexical units by performing several types of exercises: 1) Flashcards - fixing the meaning of words with cards, on one side of which is written a concept and on the other side is a definition; 2) Learn - guessing words or expressions by writing them in a special line; 3) Spell - recording words spoken by the announcer; 4) Match - correlation of the lexical unit with the picture / synonym; 5) Gravity - students must have time to write the word before the meteorite reaches the planet.

One of the effective methods, the use of which helped to increase the level of cognitive interest, is the project method, which is based on voluntary, active, creative, research activities of students, also due to the presence of personal interest in the chosen topic. Work on the projects was implemented effectively on the Trello and Padlet platforms. Within the project work, students were aware of the purpose and expected results of the activity, chose the problem and designed the idea, independently collected, analyzed and systematized the necessary information for further implementation of the action plan and public presentation of results and summarizing. In order to increase the cognitive interest of students within the educational process, time was allocated for the implementation of projects of creative, game, information, research and applied nature.

Among the pedagogical learning technologies used for the research are structural-logical schemes, tables, mental maps, infographics and scribing. In terms of blended learning, these technologies were implemented using online services "Bubbl.us", "Coggle", "Popplet" and "MindMeister", which stimulated memory, allowed students to see the essence of the problem, to discover new vocabulary in information, and the main thing is to make the learning process interesting at a distance.

At the final stage of the experiment, the effectiveness of the work was monitored, the task of which was to check the level of cognitive interest in the study of vocabulary in English lessons.

The main tasks of the control phase of the experiment were:

- study and explanation of qualitative and quantitative changes in bringing students' cognitive interest closer to the level of internal learning needs;

- analysis of the results of the formative stage of the experiment: verification of the effectiveness of the methods used in blended learning as tools to improve the dynamics of the development of cognitive interest in the acquisition of English lexical items;

- formulation of general conclusions.

The methods used at the ascertainment stage (surveys, questionnaires, 
interviews, observations, analysis and secondary education students. The results are generalization of results) were used to assess presented in diagram. the level of cognitive interest of general

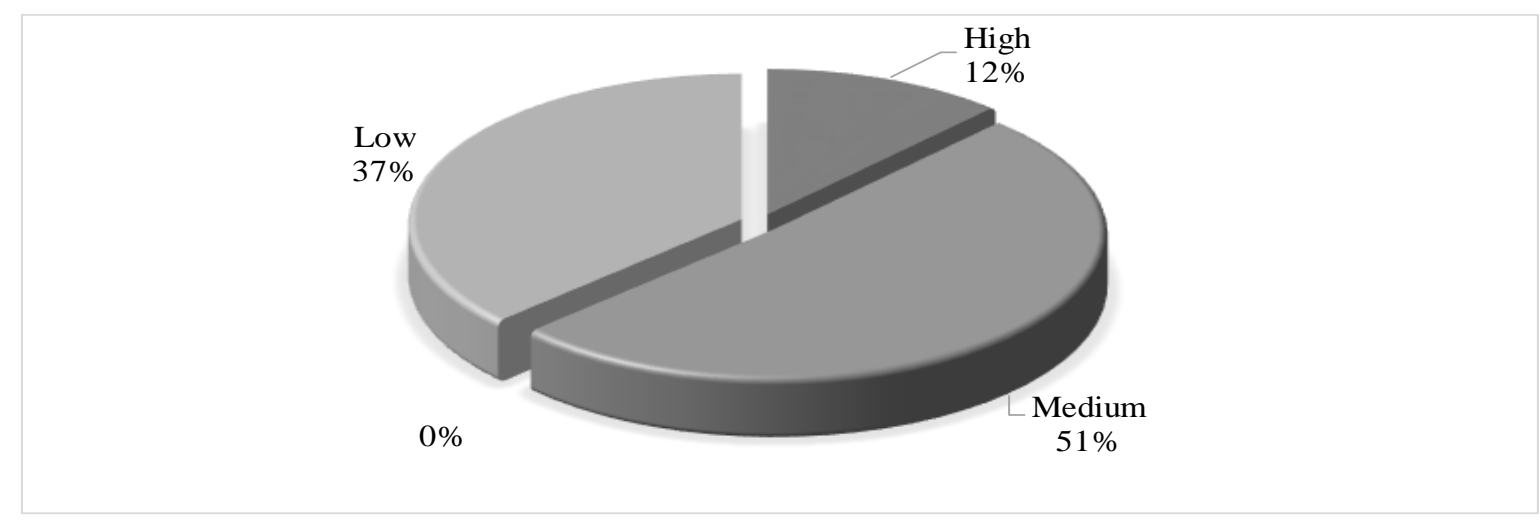

Fig. 1. The results of the ascertaining stage of the study

The analysis of the diagrams shows that the work towards the development of cognitive interest in mastering lexical competence at English lessons was carried out effectively. Zoom, Kahoot, Classroom, Jamboard, Edpuzzle, Canva, Padlet, Mentimeter, Bubbl.us were the most effective in reducing the percentage of students who were at a low level. Thanks to their use, students became more interested in mastering lexical competence in English lessons, realizing the importance of constantly expanding the vocabulary. Applicants for general secondary education were characterized by a high level of activity, intensity of work in the classroom and the desire to improve English lexical competence themselves.

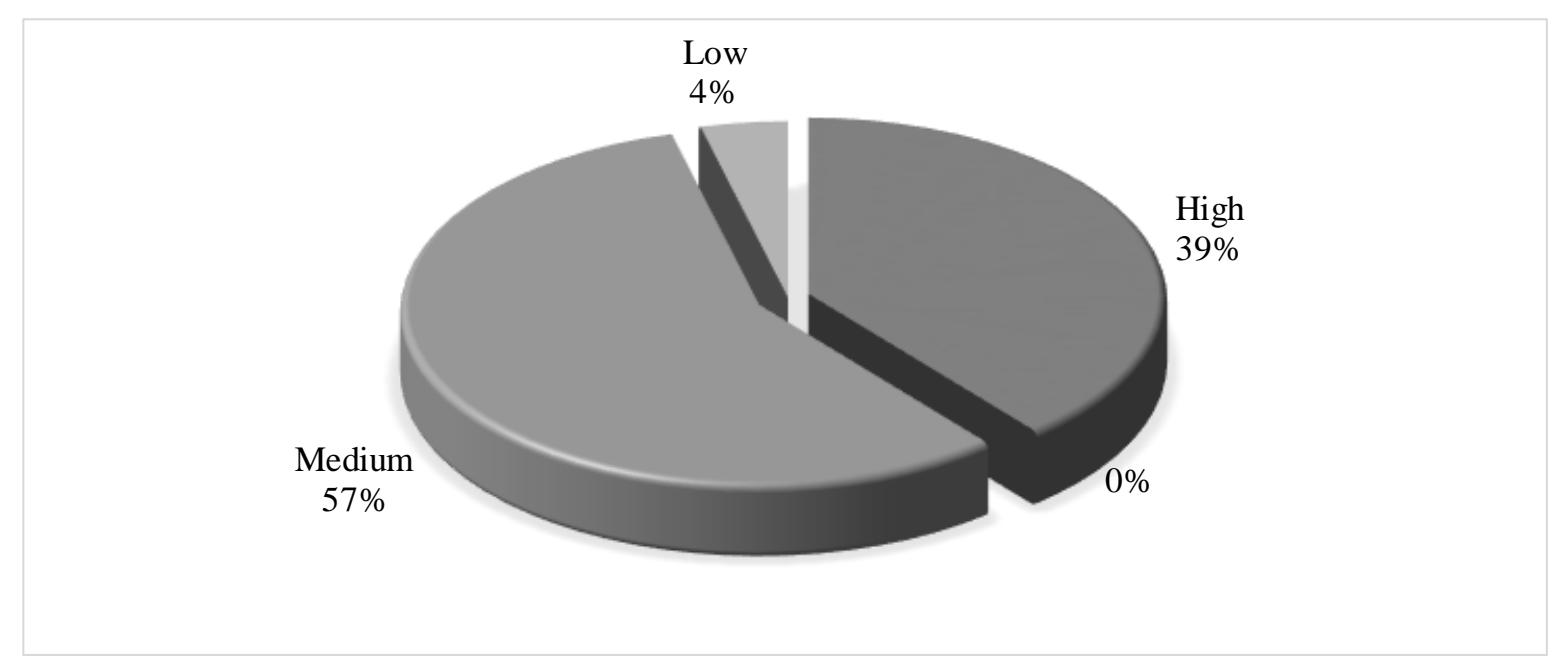

Fig. 2. The results of the control phase of the study

Conclusions of the research. Thus, after the experiment, we can state qualitative and quantitative changes in the development of students' cognitive interest in mastering the lexical competence of the English la nguage, provided the use of remote means of ICT. The study allowed us to establish that the correct gradual formation of cognitive 
interest contributes to:

$\checkmark$ mastering by students of general secondary education the necessary lexical knowledge and skills for communication in the process of performing educational tasks;

$\checkmark$ increasing the level of internal motivation

to master more educational material than required by the program at the moment;

$\checkmark$ active performance of actions for achievement of the best result of work in the conditions of mixed training;

\section{Список літератури:}

1. Стратегія розвитку вищої освіти в Україні на 2021-2031 роки. [електронний ресурс] - Режим доступу: http://www.reform.org.ua/proj_edu_strategy_ 2021-2031.pdf

2. Нова українська школа: концепттуальні принципи реформи загальноосвітньоїшколи. - [електронний ресурс] - Режим доступу: https://mon.gov.ua/ storage/app/media/zagalna\%20serednya/ nova-ukrainska-shkola compressed.pdf

3. Башкир О. I., Ільченко А. Р. Пізнавальний інтерес як умова оволодіння лексичною компетенцією англійської мови / О. І. Башкир, А. Р. Ільченко // Науковий часопис Національного педагогічного університету ім. М. Драгоманова. Серія 5. Педагогічні науки: реалії та перспективи. Збірник наукових праць. М-во освітності і науки України, Нац. пед. ун-т ім. М. Драгоманова. - Київ: Видавничий дім “Хелветтика". - 2021. - Вип. 77

4. Бібік Н. М. Формування пізнавальних інтересів молодих школярів / Н. М. Бібік. - Київ: Віпол. -1987. - С. 96

5. Бондаревський В. Б. Виховання інтересу до знань i потреб до самоосвітності / В. Б. Бондаревський // Книга для вчителя. Москва:Просвіщення. - 1985. - C. 144 $\checkmark$ emergence of students' inner need for independent acquaintance with a significant amount of new lexical units for them, which is important during distance learning.

The study does not exhaust the outlined problem completely. A promising area of research can be to identify the effectiveness of distance learning at the level of mastering the language competence of students of general secondary educational institutions.

\section{6. Бухбиндер В. А. Основи} методики підготовки однозначних язиків / В. А. Бухбиндер. - Київ: Вища школа. 1986. - C. 335

7. Лозова В. І. Цилісний підхід до формування пізнавальної активності школярів / В. І. Лозова. - Харків: “ОВС”. 2000. - C. 164

8. Сіранчук Н. М. Формування лексичної компетенції в навчанні початкових класиків на уроках української мови / Н. М. Сіранчук // дис. докт. пед. наук: 13.00.02. - Рівне:. - 2018. - С. 428

9. Терещук B. X. Принципи формулювання англомовної лексичної компетентності студентів немовним спеціалістом в умовах віртуального навчального середовища / В. Х. Терещук // Серія Педагогіка та психологія: Вісник КНЛУ. - 2013. - Вип. 22. - С. 161-171

10. Щукіна X. Й. Педагогічні проблемні формування пізнавальних інтересів учнів / Х. Й. Щукіна. - Москва: Педагогіка. - 1988. - С. 208

11. Чан В. М. Медіа у навчанні та навчанні іноземних мов. / В. М. Чан // Навчання в галузі навчання другої та іноземних мов. - Бостон: Вальтер де Груйтер. - 2011. - С. 422

12. Meara Paul The Dimensions of Lexical Competence, available at: https://www.lognostics.co.uk/vlibrary/meara1 996a.pdf 


\section{References:}

1. Strategy for the development of higher education in Ukraine for 20212031, available at: http://www.reform.org.ua/ proj_edu_strategy_2021-2031.pdf

2. New Ukrainian school: conceptual principles of the secondary school reform, available at: https://mon.gov.ua/storage/app /media/zagalna\%20serednya/novaukrainska-shkola compressed.pdf

3. Bashkir, O. I., Ilchenko, A. R. (2021), "Cognitive interest as a condition for mastering the lexical competence of the English language", "Scientific journal of the National Pedagogical University named after Drahomanov, M. Series 5", "Pedagogical sciences: realities and prospects. Collection of scientific works, Ministry of Education and Science of Ukraine, Nat. ped. Drahomanov M. University", no. 77, Kyiv: Helvettika Publishing House

4. Bibik, N. M. (1987), "Formation of cognitive interests of young schoolchildren”, Kyiv: Vipol, p. 96

5. Bondarevsky, V. B. (1985),

"Education of interest in knowledge and needs for self-education: a book for teachers", Moscow: Enlightenment, p. 144

6. Buchbinder, V. A. (1986),

"Fundamentals of methods of preparation of unambiguous languages", Kyiv: Higher School, p. 335

7. Lozova, V. I. (2000), “A holistic approach to the formation of cognitive activity of students", Kharkiv: OVS, p.164

8. Siranchuk, N. M. (2018), "Formation of lexical competence in primary school students in Ukrainian language lessons: dis. Dr. Ped. Science: 13.00.02", Exactly:, p. 428

9. Tereshchuk, V. H. (2013), "Principles of formulation of English lexical competence of students by a non-language specialist in the conditions of virtual educational environment", "Bulletin of the KNLU, Series Pedagogy and Psychology", issue 22, pp. 161-171

10. Schukina, H. Y. (1988), "Pedagogical problem formation of cognitive interests of students", Moscow: Pedagogy, p. 208

11. Chan, V. M. (2011), "Media in teaching and learning foreign languages. Training in the field of teaching second and foreign languages", Boston: Walter de Gruiter, p. 422

12. Meara Paul The Dimensions of Lexical Competence, available at: https://www.lognostics.co.uk/vlibrary/meara 1996a.pdf 